研究

\title{
鉄系粉末金型潤滑成形法の最適化と㧞出し挙動の動的および静的摩擦解析
}

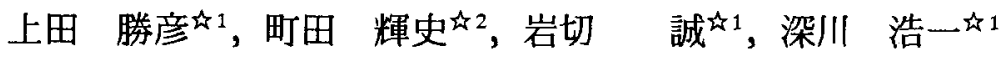 \\ 的日立粉末冶金(㑣)，广270-2295 松戸市稔台 520 . \\ 的玉川大学工学部, 干 194-8610 町田市玉川学園 6-1-1。
}

\section{Optimization of Die-wall Lubrication Compacting Method of Iron Powder and Static/Kinetic Friction Analysis of Ejection Behavior}

\author{
Katsuhiko Ueda ${ }^{\text {1 }}$, Terufumi Machida ${ }^{\text {22 }}$, Makoto Iwakiri ${ }^{\text {h1 } 1}$ and Hirokazu Fukagawa ${ }^{\text {th } 1}$ \\ ${ }^{4} 1$ Hitachi Powdered Metals Co.,Ltd., 520 Minoridai, Matsudo 270-2295. \\ 42 Department of Mechanical Engineering, Tamagawa University, 6-1-1 Tamagawa Gakuen, Machida 194-8610.
}

Received June 5, 2001

\begin{abstract}
SYNOPSIS
The present paper describes a new evaluation for ejection behavior in iron powder compacting process and optimum die-wall lubrication conditions. In the new method, ejection force is broken down to static friction force and kinetic friction force, which make it possible to explain ejection behavior more clearly. The incremental rate of kinetic ejection force is more important for surface quality of compacts than the value of static ejection force. Among three lubricants used, zinc stearate showed the highest static ejection force but the lowest incremental rate of kinetic ejection force. It also showed an excellent surface quality of the compacts. Characteristic crystalline structure gave a low shear strength, which contributed to decrease the kinetic friction. In the die-wall lubrication method, the projected area rate of lubricant particles should be $90 \%$ or more, therefore, the multiple coating method which is repetition of short time shot is requested.
\end{abstract}

KEYWORDS

high-density, compaction, die-wall lubrication, ejection, static frictional force, kinetic frictional force

\section{1 緒 言}

粉末焼結製品の高密度・高強度化に優れているとされる金 型潤滑成形に関して，近年，アメリカのZinc Corp. of America のWalter G. Ball ら ${ }^{1-3}$ によって静電粉体染装の技術を応用した 乾式の金型潤滑法が開発され，実用化にもっとも近い手法と して注目されている。乾式潤滑法の大きな利点は, 従来の粉 末潤滑法(原料粉末内に潤滑剂を添加する手法)と同種の潤滑

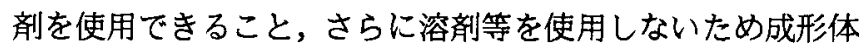
の污染がないことである.

金型潤滑による高密度成形法の開発にあたって著者らは前 報で，原料粉末への潤滑剂添加量が成形体の密度に及ほす影 響と粉末一金型間ならびに粉末間の摩擦に及ぼす影響を明ら かにし，鉄系粉末に添加する成形潤滑剤量を最適化または最 小化した包。本報では，静電粉体金型潤滑法において，成形体 の高密度化とともに重要な拔出し性について検討を行った。 抜出し压力を静摩擦と動摩擦の両力場で評価する新しい手法 を用いて, 各種潤滑郕の性能, カジリ・凝着現象の発生, 潤 滑方法について新たな知見を得た。

\section{2 実験方法}

\section{1 供試粉末および供試潤滑剂}

鉄粉は，水アトマイス鉄粉アトメル $300 \mathrm{M}$ (侏)神戸製鋼所， 粒径: $150 \mu \mathrm{m}$ 以下) と，それを笠で $44 \mu \mathrm{m}$ 以下に分級したもの を用いた。

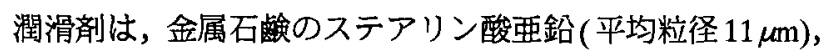
ステアリン酸リチウム(平均粒径 $15 \mu \mathrm{m})$, ならびにワックス系 蘭滑剂のエチレンビスアミド (平均粒径 $17 \mu \mathrm{m}$ ) である。潤滑 郕を 0.8 1.4 mass\%の範囲で鉄粉に添加し，V型混合機で $20 \mathrm{~min}$ 間混合した．なお，金型潣滑法を適用する供試粉末は潤滑剂

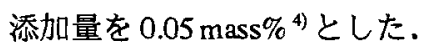

\section{2 金型润滑の方法}

金型潣滑には，Fig.1 に示すような静電粉体潤滑装置 ${ }^{5)}$ (Gasbarre Products Inc. 製)を用いた.ホッパーエアにより流動 状態にされた潤滑剂は，送り込まれた潤滑エアによってベン チュリ効果で吸い上げられ，エアとともに帯電ガンに送られ る. 帯電ガンエアで加速された潤滑珬粒子は，樹脂との摩擦 でプラスに帯電し噴射され，アースしたダイスに接近すると 
マイナスの鏡像電荷が誘起されるため静電引力によりダイス 内壁面に付着する。

実験では，ダイス内の所定位圆に下パンチを挿入後，成形 に支障のないダイス内壁面に $15 \mathrm{~mm} \times 10 \mathrm{~mm}$ の金属テーブを貼 付して润滑剤を塗布した。そして成形を開始する前にテープ を剥離し，塗布状態を金属顕微鏡で観察後，その润滑片粒子 の投影面積比を画像解析装置で算出して塗布面積率を確認し た.涩布面積率 $\mathrm{A}_{c}$ は式 (1)により求めた。

$$
\mathrm{A}_{c}=\mathrm{A}_{\mathbf{1}} / \mathrm{A}_{d}
$$

ここでAおよびAdは，それぞれ顕微鏡視野内における潤滑郕 粒子の投影面積と金属テープ面積 (ダイス内壁面積を意味する) である。

このとき潤滑エア圧を $138 〜 276 \times 10^{3} \mathrm{~Pa}$ ，塗布時間を $0.1 \sim 3 \mathrm{~s}$ の範囲でそれぞれ変化させた. なお, 帯電ガンエア圧は 207× $10^{3} \mathrm{~Pa}$ とした.

\section{3 成形及び抜出し方法}

アムスラー型万能試験機を用い，圧力 $200 \sim 1000 \mathrm{MPa}$ の範 囲で円柱試験片に圧粉成形した。試験片寸法は，直径 $20 \mathrm{~mm}$ で高さ30 mmである.ダイスからの抜出し法の模式を Fig.2に 示す. 固定ブロック上のダイス内にノックアウトパンチを挿 入しロードセルをセットした後, クロスヘッド速度 $2.9 \mathrm{~mm} / \mathrm{s}$ でパンチを降下した。

2.4 拔出し性の評価

実験手順としては，まず粉末潤滑法での抜出し圧力を評価 し，その結果を金型潤滑法に適用することにした。拔出し挙 動を評価するために，拔出し荷重一変位関係を計測しX-Tレ コーダに記録した。

抜出し性の評価方法を模式的に Fig.3に示す。一般に，抜出し 荷重ーパンチストローク(変位)線図は初めの直線部と,その 後の緩やかな曲線部に分かれる.直線の終点(a)の荷重は成形 体とダイス壁面との最大静止摩擦力を意味し，ここから成形 体が抜出され始める．その後の緩やかに上昇する曲線 $(\mathrm{b} \rightarrow \mathrm{c})$

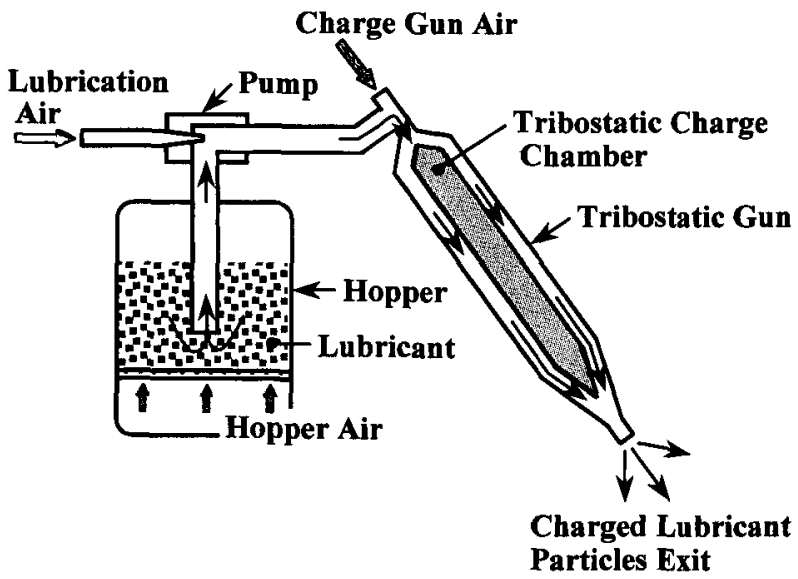

Fig.1 Schematic illustration of die-wall lubrication system (electrostatic powder coating method)
は動摩擦力の增加を示し, 成形体の先端がダイスから出始め る(c)点で最大值を取り，完全に抜け落ちた時点 (d)で零とな る.すなわち，抜出し圧力 $\sigma_{\mathrm{e}}$ は次式によって表せる。

$$
\begin{aligned}
& \sigma_{\mathrm{c}}=\sigma_{\mathrm{s}}+\Delta \sigma_{\mathrm{k}} \\
& \sigma_{\mathrm{s}}=\mathrm{Ps} / \mathrm{A} \\
& \Delta \sigma_{\mathrm{k}}=(\mathrm{t}+\mathrm{l}) \cdot \tan \theta\left(\tan \theta: \mathrm{MPa} \cdot \mathrm{mm}^{-1}\right)
\end{aligned}
$$

ここで， $\sigma_{\mathrm{s}}$ は (a) 点における荷重 Ps を試験片の側面積 A で除 した值であり，静的抜出し圧力と定義することにした.

$\Delta \sigma_{k}$ は抜出し圧力の最大增加割合(動的抜出し圧力)を示す. この動摩擦挙動は, 加圧終了後, ダイス壁面に発生する成形 体のスプリングバックカを直接測定して抜出し行程中の動摩 擦力を求めることが困難なので，(b) と (c) 点を直線で結んで できる仰角 $\theta$ (degree)を評価し，動的抜出し圧力の増加係数と

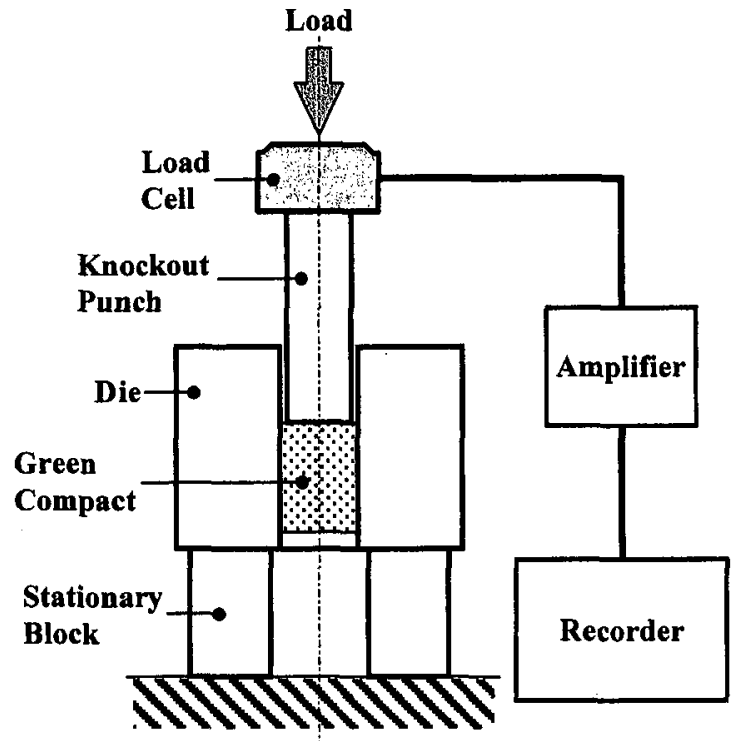

Fig.2 Ejecting of green compact and measuring method of the ejection force.

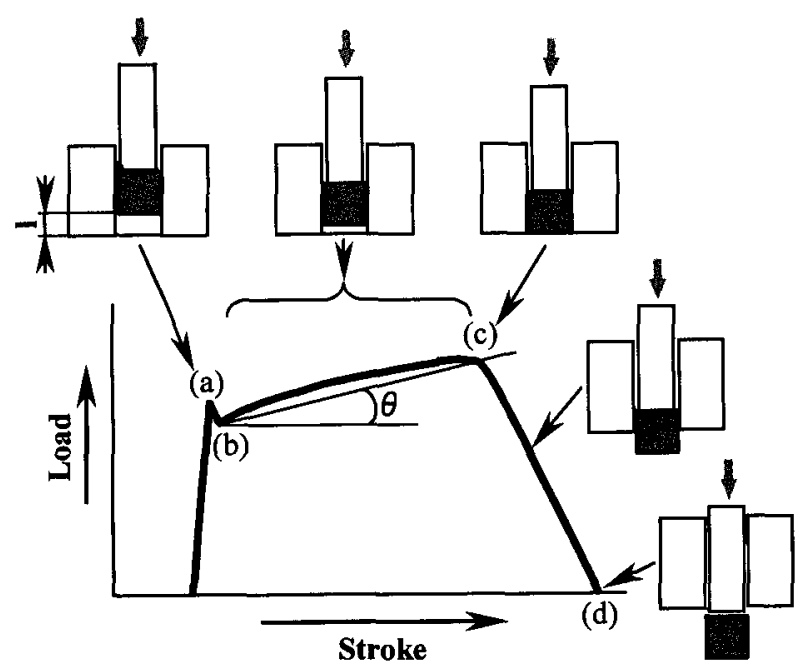

Fig.3 Load-punch stroke diagram and definition of static ejection force (a) and incremental rate of kinetic ejection force $(\theta)$. 
定義することにした。 $\mathrm{t}$ は試験片の高さ，1は図中に示すよう に試験片下面からダイス下面までの距離である．この両者の 和がパンチストロークであり，本実験では全て一定である. また $\sigma_{\mathrm{s}}$ は主に側圧力, 粉末のポアソン比ならびに弾性係数, 金型の弾性係数に， $\Delta \sigma_{\mathbf{k}}$ は主に润滑剂の滑性，成形体とダイス 内壁面での凝着・カジリ度合い，ダイス内壁面粗さ等により 影響される值である.なお，ダイス内壁面粗さ $(\mathrm{Rt})$ は，加圧 軸方向 $0.43 \mu \mathrm{m}$, 円周方向 $1.0 \mu \mathrm{m}$ である.

粉末潤滑法では各条件において試験数を 3 回とし，その平 均值を求めた。.また，いずれの潤滑法においても，抜出し終 了毎にダイス内壁面に残った潤滑剂等の凝着物を\#800のエメ リ一紙で除去後, アセトンにて洗浄した。

さらに $600^{\circ} \mathrm{C} て ゙ 2$ 時間, Endothermic Gas 雾囲気で脱ろうし た円柱試験片の摺動面を，両端からそれそれ約 $5 \mathrm{~mm}$ と中央部 の3ケ所, 走查電顕 (SEM) で観察した.

\section{3 実験結果}

3.1 静的抜出し圧力に及ぼす潤滑剂，成形任力，鉄粉粒度の影響 潤滑剂添加量が及ぼす静的抜出し圧力の影響を Fig.4に示 す.これは, 粒径 $150 \mu \mathrm{m}$ 以下の通常の鉄粉を使用し, 成形圧 力 $700 \mathrm{MPa}$ 一定とした場合の例である. 図から, 静的抜出し 圧力は潤滑剂添加量の増加にともなって低下し，その水準は 澗滑剂にステアリン酸重鉛を用いた場合が最も高く，次にエ チレンビスアミド，そしてステアリン酸リチウムが最も低い 值を示すことが分かる。

成形圧力と静的抜出し圧力との関係を Fig.5に示す。潤滑剤 添加量は一定(1mass\%)とした。図から，一般に成形圧力が高 くなると静的抜出し圧力か增加し成形圧力 $1000 \mathrm{MPa}$ 以上では

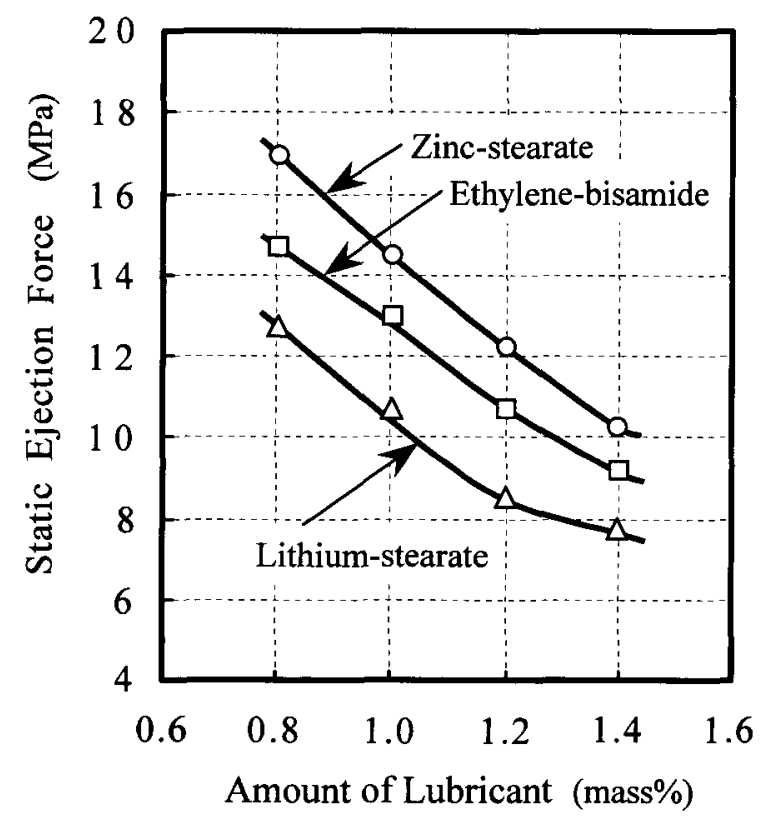

Fig.4 Effects of lubricant amount and lubricant type on static ejection force in powder lubrication method (compacting pressure: $700 \mathrm{MPa}$ ).
僅かに低下することが分かる，潤滑剤の効果を見ると，低い 成形圧力では目立たないものの成形圧力 $600 \mathrm{MPa}$ 以上で増加 割合が顕著な差を示し，高圧側ではステアリン酸亜鉛が最も 高く, エチレンビスアミドが次位で, ステアリン酸リチウム が最も低い值を示すことが分かる。

また，図中に中実円プロット(の)で示した曲線は, ステア リン酸覀鉛潤滑で，鉄粉粒径 $45 \mu \mathrm{m}$ 以下の值である，中空円 プロット(O)のものと比較すると，低い成形圧力領域ではそ の影響が少ないものの, 成形圧力 $600 \mathrm{MPa}$ 以上では粒径の小 さい方が約 $23 \%$ 程度低い值になることが分かる。

3.2 動的抜出し圧力の増加係数に及ぼす润滑剤, 成形圧力, 鉄 粉粒度の影響

動的抜出し圧力の增加保数に及ぼす潤滑剂添加量の影響を Fig.6に示す. 成形は, 粒径 $150 \mu \mathrm{m}$ 以下の鉄粉を使用し, 圧力 $700 \mathrm{MPa}$ で行っている. 図から，一般に潤滑剤添加量が增すに つれて動的抜出し圧力の增加係数が低下すること, その傾向 はステアリン酸曲鉛が最も小さく，次位がステアリン酸リチ ウム, そしてエチレンビスアミドの場合に最も顕著であるこ とが分かる。

動的拔出し圧力の增加係数に及ぼす成形圧力の影響をFig.7 に示す．これは潤滑剤添加量が $1 \mathrm{mass} \%$ の場合である. 図から， ステアリン酸覀鉛は潤滑剤 3 種のうちで特異な挙動を示すこと が分かる.すなわち, ステアリン酸亜鉛は成形圧力 $400 \mathrm{MPa}$ 最大值を示し, それより高い圧力では急激に低下し $1000 \mathrm{MPa}$ では負の值を取るようになる，眓の中空円と中実円のプロッ

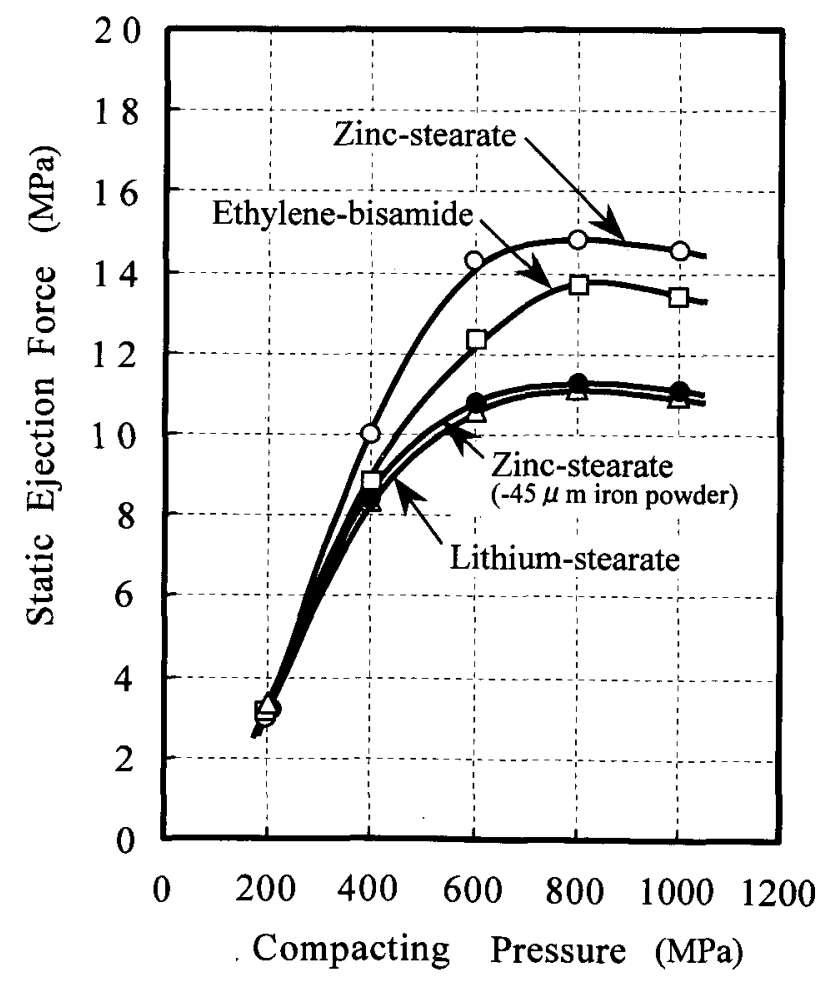

Fig.5 Effects of compacting pressure, lubricant type and powder grain size on static ejection force in powder lubrication method (amount of lubricant: 1 mass $\%$ ). 
卜を比較すると，両者の傾向は鉄粉粒径にほとんど影響され ないことが分かる。

これに対して，ステアリン酸リチウムは成形圧力 $600 \mathrm{MPa}$ 近傍で急增し，800MPaで最大となり $1000 \mathrm{MPa}$ で滅少に転ず る.エチレンビスアミドは成形圧力 $800 \mathrm{MPa}$ までほぼ直線的 に上昇し，これもまた $1000 \mathrm{MPa} て ゙$ て隇少に転ずる。

3.3 成形体の表面状態

抜出し工程中にダイス内壁面と接触していた鉄粉粒子の状 態を知るために，代表的な成形体(成形圧力 $800 \mathrm{MPa}$ ，潤滑骩 添加量 1 mass\%)の表面を観察した. その結果を Fig.8に示す. 抜出しは上パンチから下パンチ方向へと行ったので，上パン 千近傍の成形体表面がもっとも長い摺動距離を取っている.

図 (a)のステアリン酸亜鉛の場合には, 抜出し初期 (下パン 于側)から後期 (上パンチ側)に至るまで鉄粉粒子の状態にほ とんど変化が認められない.これに対して, 図(b)のステアリ ン酸リチウムの場合には，抜出しの進行にともなってダイス との摩擦によって生じた粒子の塑性変形が次第に大きくなる とともに表面の気孔も減少していることが分かる。図(c)のエ チレンビスアミドの場合には試験片中央部からすでに粒子の 大きな塑性変形と表面気孔の減少, さらに抜出し方向に沿っ た摺動傷が観られ，抜出し後期では凝着・焼付きの様相を呈 している.

3.4 塗布面積率に及ほす金型潤滑剤塗布条件の影響

金型潤滑法において，潤滑エア圧力ならびに塗布時間が潤 滑郕の塗布面積率に及ぼす影響をFig.9に示す. 金型潤滑剂に は，瀷動表面損傷の少なかったステアリン酸亜鉛を用いた。 図 (a) から，塗布面積率は潤滑エア圧力 $200 \times 10^{3} \mathrm{~Pa}$ 近傍で急激

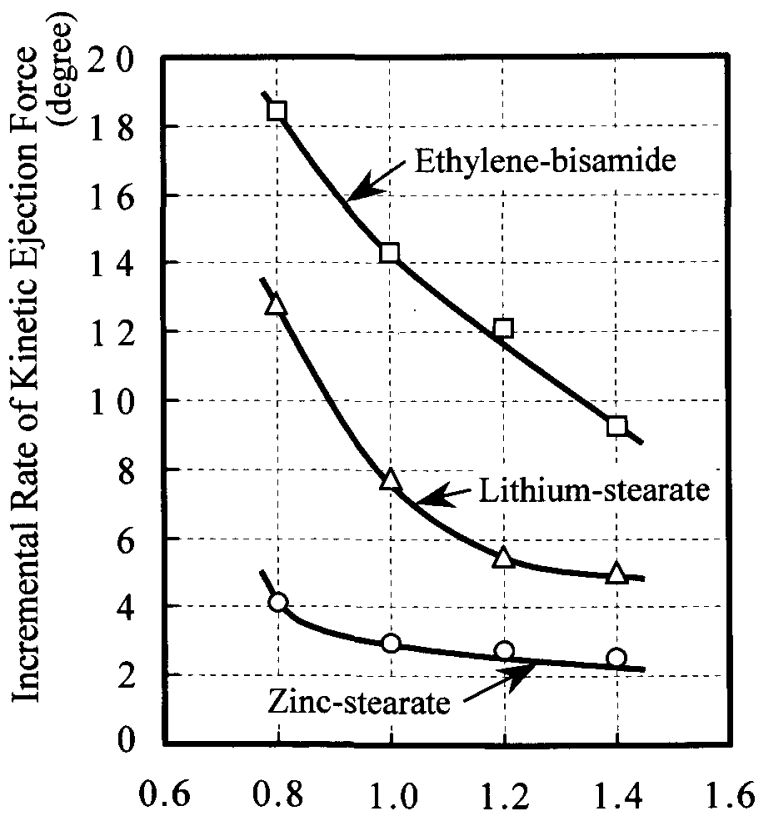

Amount of Lubricant. (mass\%)

Fig.6 Effects of lubricant amount and lubricant type on incremental rate of kinetic ejection force in powder lubrication method (compacting pressure: $700 \mathrm{MPa}$ ).
に増加し，それ以上では徐々に増加することが分かる。なお

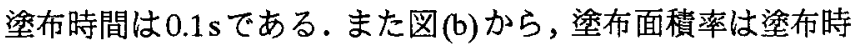
間とともに増加し，その傾向は2s以上でやや緩やかになるこ とが分かる。

潤滑エア圧力 $207 \times 10^{3} \mathrm{~Pa}$ ，時間 $0.1 \mathrm{~s}$ 一定とし，塗布回数と 面積率の関係を調查した結果を Fig.10に示す．図から，梁布 回数 1 回では面積率 $59.6 \%$ と低いものの, 2 回では潤滑剤粒子 がほぼダイス内壁面全体を覆う状態の $95.5 \%$ と高い水準にな ることが分かる。

3.5 金型潤滑法における静的抜出し圧および動的抜出し圧力 の増加係数

潤滑剂の塗布面積率が静的抜出し圧力および動的拔出し圧 力の増加係数に及ぼす影響を Fig.11(a),(b)に示す. 塗布面積 率は潤滑エア圧力, 時間ならびに塗布回数を調整して変化さ せた。成形圧力は $700 \mathrm{MPa}$ である. 図から，静的报出し圧力 および動的抜出し圧力の増加係数ともに，塗布面積率が大き くなるにつれて単調に低下することが分かる。ちなみにステ アリン酸亜鉛を 1 mass\% 添加した粉末潤滑法と同等水準の静 的抜出し圧力と動的抜出し圧力の增加係数は，梁布面積率 90\%以上で详成できることが分かった。

\section{4 考察}

4.1 抜出し圧力における静摩擦力と動摩擦力について 金型潣滑成形において重要な評価の一つとされる拔出し性

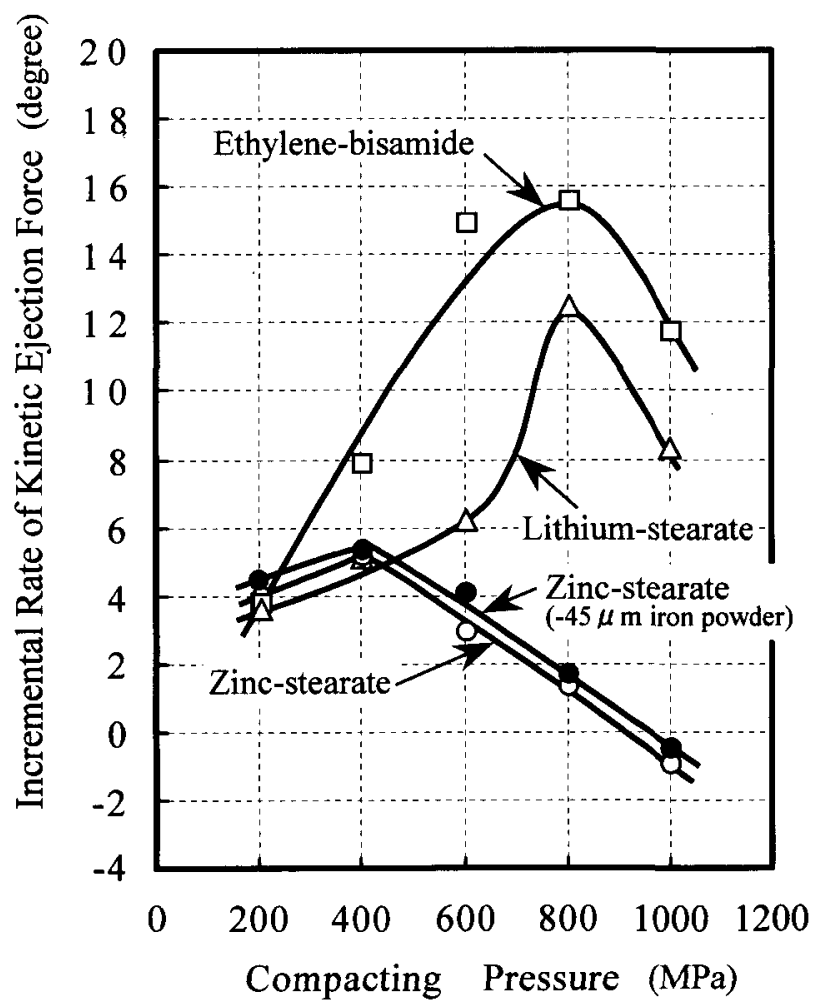

Fig.7 Effects of compacting pressure and powder grain size on incremental rate of kinetic ejection force in powder lubrication method under various lubricants (amount of lubricant: 1 mass\%). 
について検討を行った．抜出し性の評価は，抜出し荷重の減 少と成形体の形状保持および性状保存のために必要であると 考えられる. 通常, 拔出し荷重は成形荷重に比ぺて小さいの

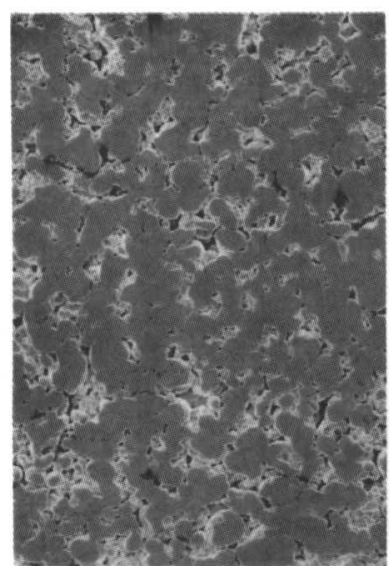

Upper punch side

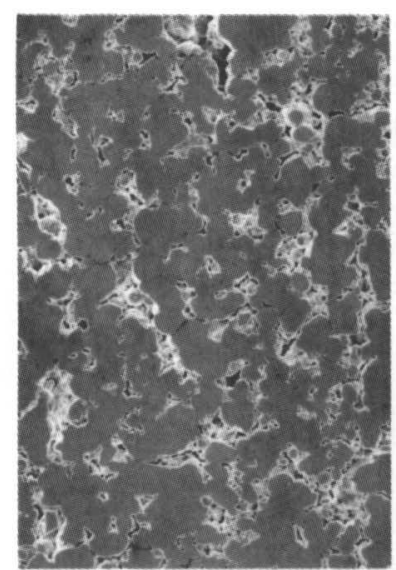

Middle

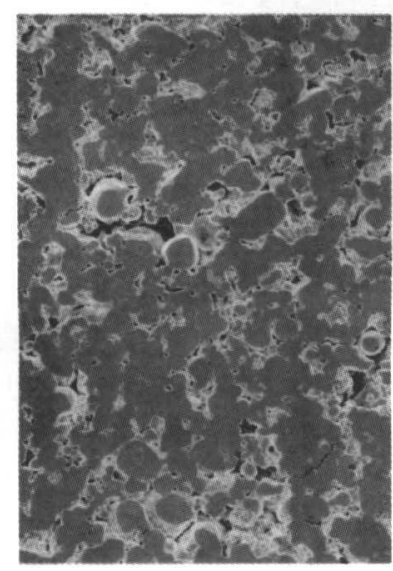

Lower punch side

(a)Zinc-stearate

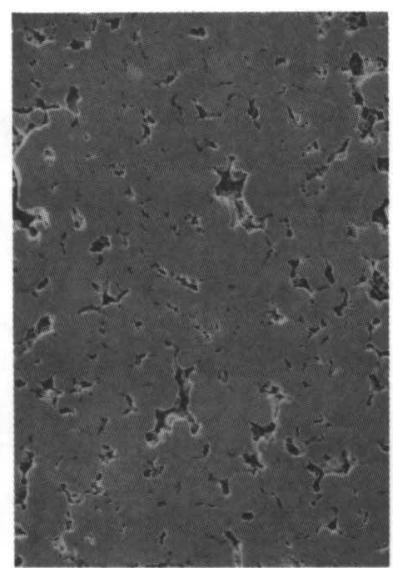

Upper punch side

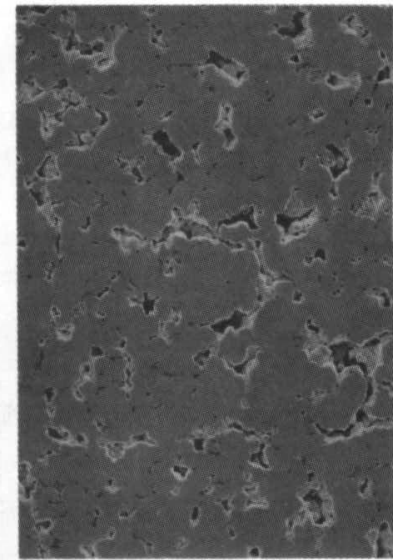

Middle

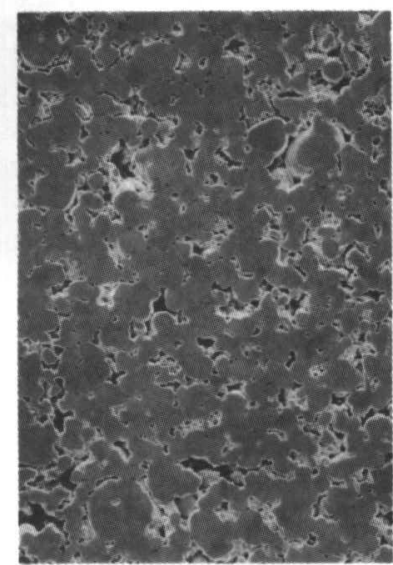

Lower punch side

(b) Lithium-stearate
で, 後者の視点の方が重要である.一般に, 拔出し性はJPMA (P13)に規定されているように, 抜出し工程中の最大荷重值を 評価する。しかし，それのみでは得られた成形体表面性状の
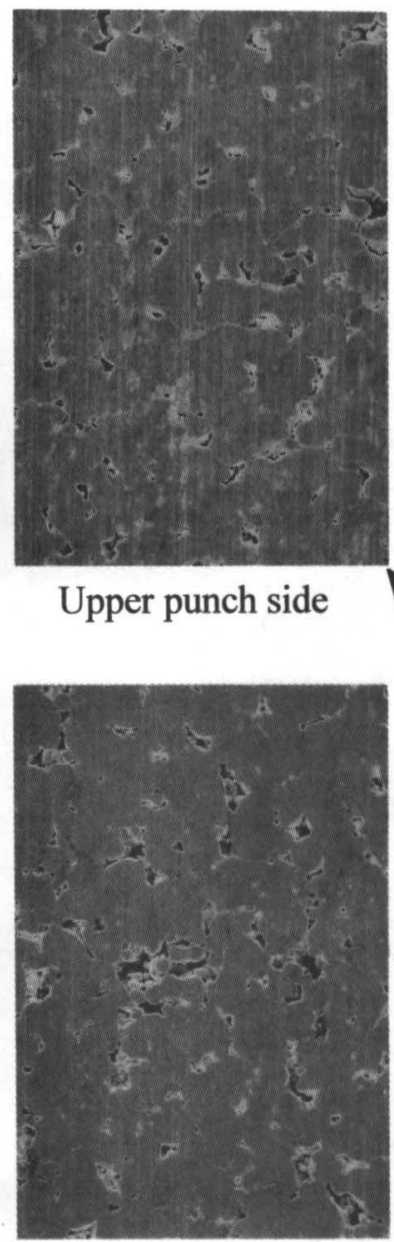

Ejecting direction
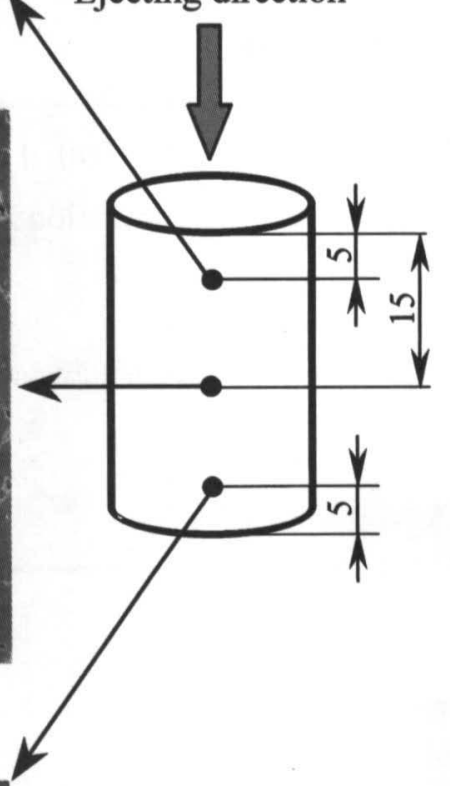

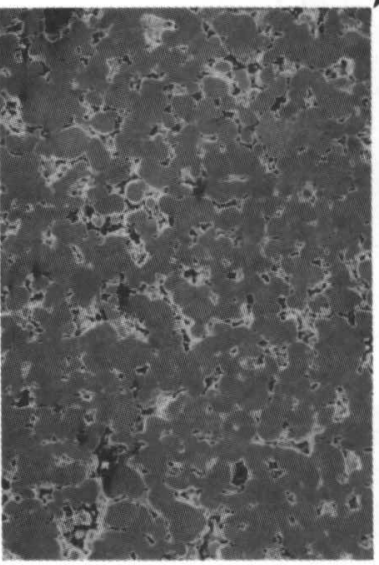

Lower punch side

(c) Ethylene-bisamide

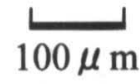

Fig.8 Appearances of green compact surfaces, observed by a scanning electron microscope (compacting pressure: $800 \mathrm{MPa}$, amount of lubricant: 1 mass \%) 


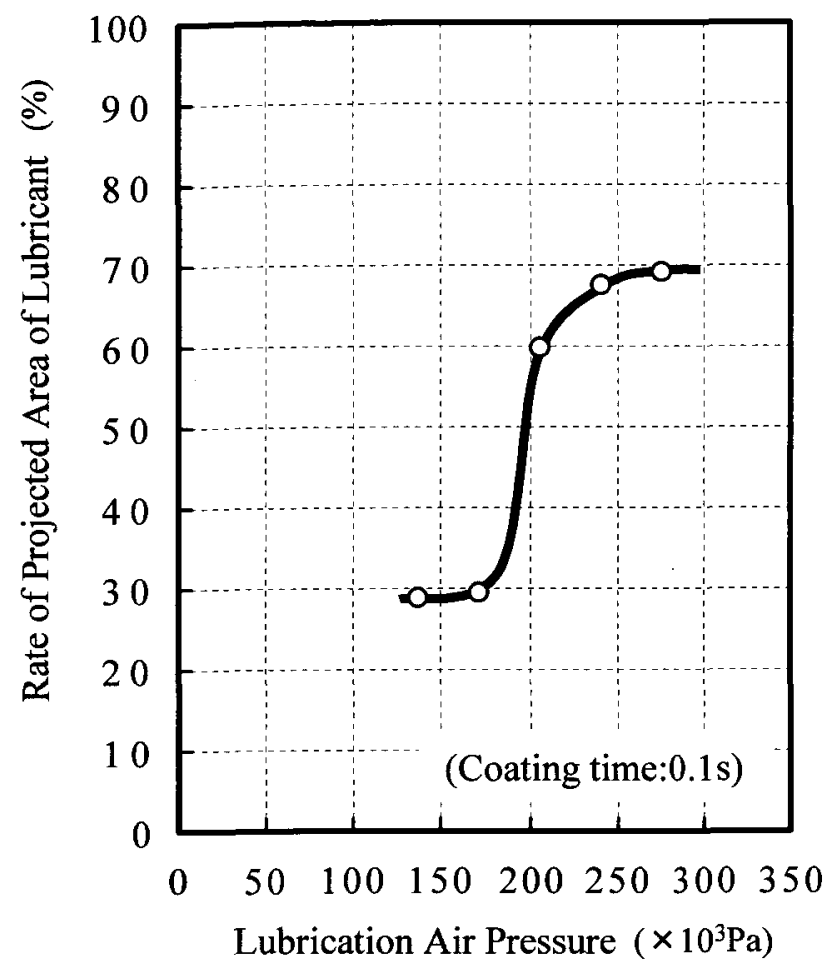

(a)

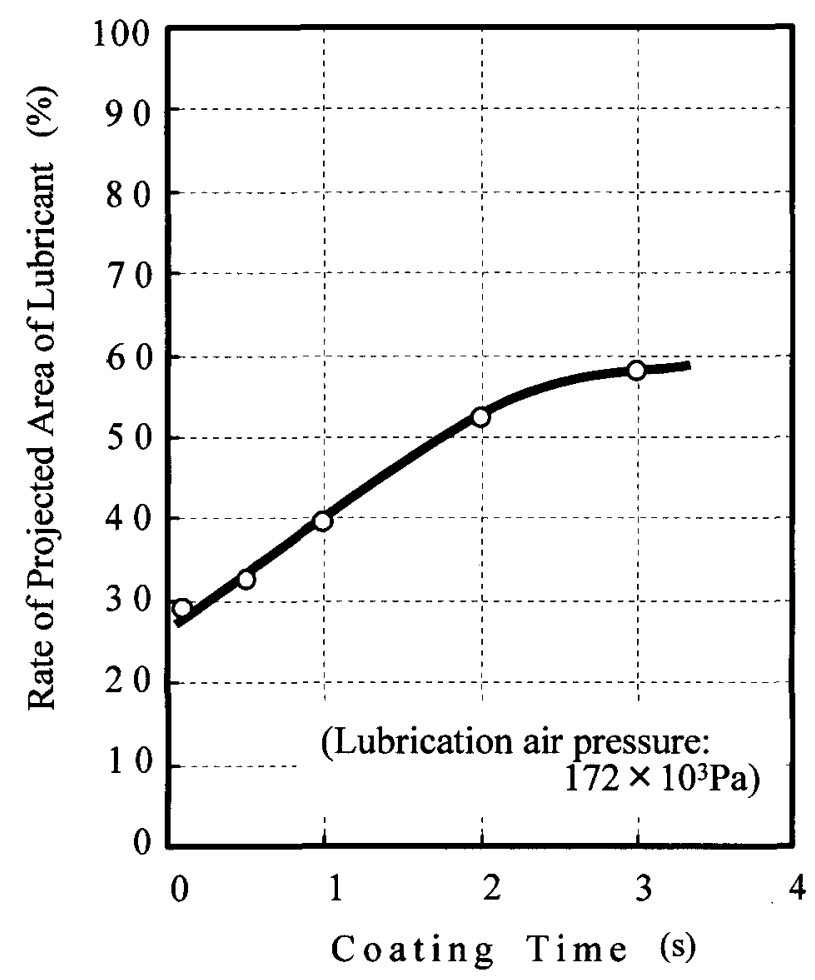

(b)

Fig.9 Effects of lubrication air pressure and coating time on rate of projected area of lubricant (charge gun air: $207 \times 10^{3} \mathrm{~Pa}$ ).

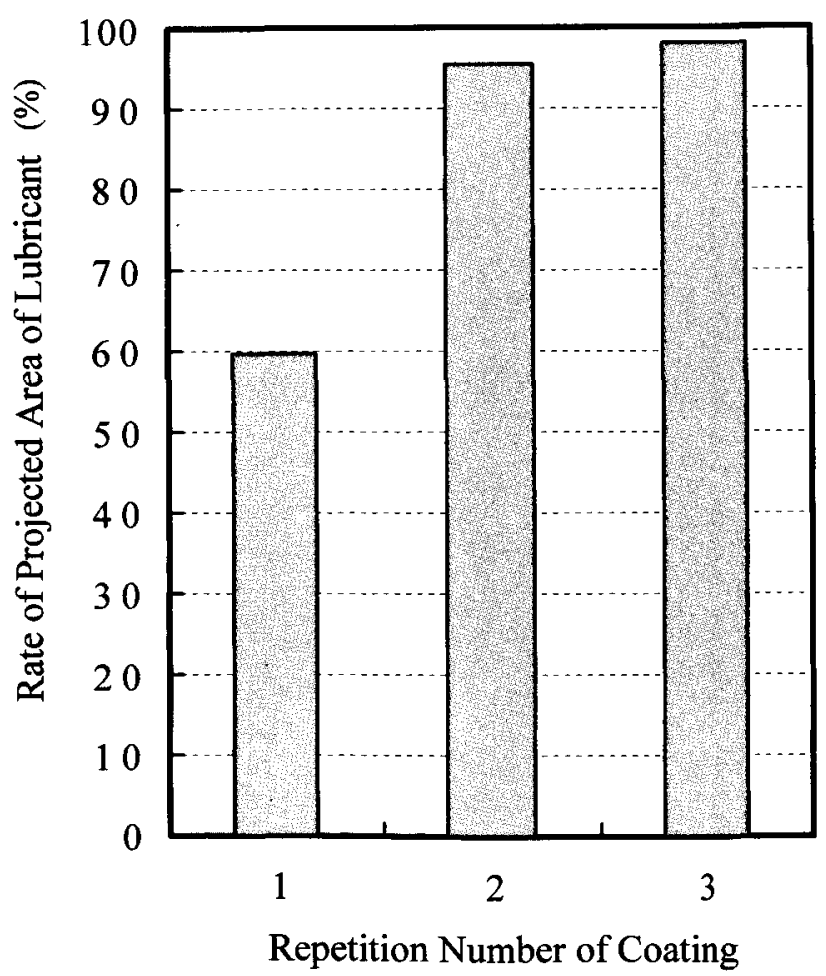

Fig.10 Increase of rate of projected area of lubricant by repeated coating (lubrication air: $207 \times 10^{3} \mathrm{~Pa}$, coating time: $0.1 \mathrm{~s}$, charge gun air: $207 \times 10^{3} \mathrm{~Pa}$ ).
相関に満足できない事例がしばしば発生している。例えば， 実験結果のFig.4およびFig.5に示す静的抜出し圧力の大小は， Fig.8に示す成形体表面の性状に全く対応しないことが分か る.そこで，抜出し性または抜出し圧力を構成要素すなわち 静摩擦力と動摩擦力に区別して評価する手法を試みた。

その結果として, Fig.6やFig.7に示すように，動的抜出し圧 力の増加係数が小さいものは成形体表面性状も良好であるこ となどそその両者の間に強い相関が見出された．抜出し性の 評価には動摩擦力の変化を精確にとらえることが必要である ことを明らかにした。

いま純鉄系の一般的な成形条件である潤滑放添加量 1 mass\%， 圧力 $700 \mathrm{MPa}$ での静的抜出し圧力は, Fig.4から, ステアリン 酸無鉛 $14.4 \mathrm{MPa}$ ，ステアリン酸リチウム $10.7 \mathrm{MPa}$ となる。ま た,動摩擦工程の最終点(Fig.3のb点)における抜出し圧力は, 荷重一ストローク線図から，ステアリン酸覀鉛は $15.2 \mathrm{MPa}$, ステアリン酸リチウムは $13.8 \mathrm{MPa}$ となる.したがって，抜出 し中の最大荷重值のみを評価する従来法によれば, ステアリ ン酸リチウムの方がステアリン酸垔鉛よりも抜出し性の優れ た潤滑剤と言うことになるが, Fig.6から，ステアリン酸严鉛 の動的抜出し圧力の增加係数はステアリン酸リチウムに比べ 2.7 倍程度小さく，しかも表面性状も良好であった。

ステアリン酸垔鉛が最も優れた抜出し性を示した原因の一 つとして，次のことが考えられる、ステアリン酸要鉛の結晶 は $\left(\mathrm{C}_{17} \mathrm{H}_{35} \mathrm{COO}\right)_{2} \mathrm{Zn}$ の化合物の層状構造である。この層は金属 


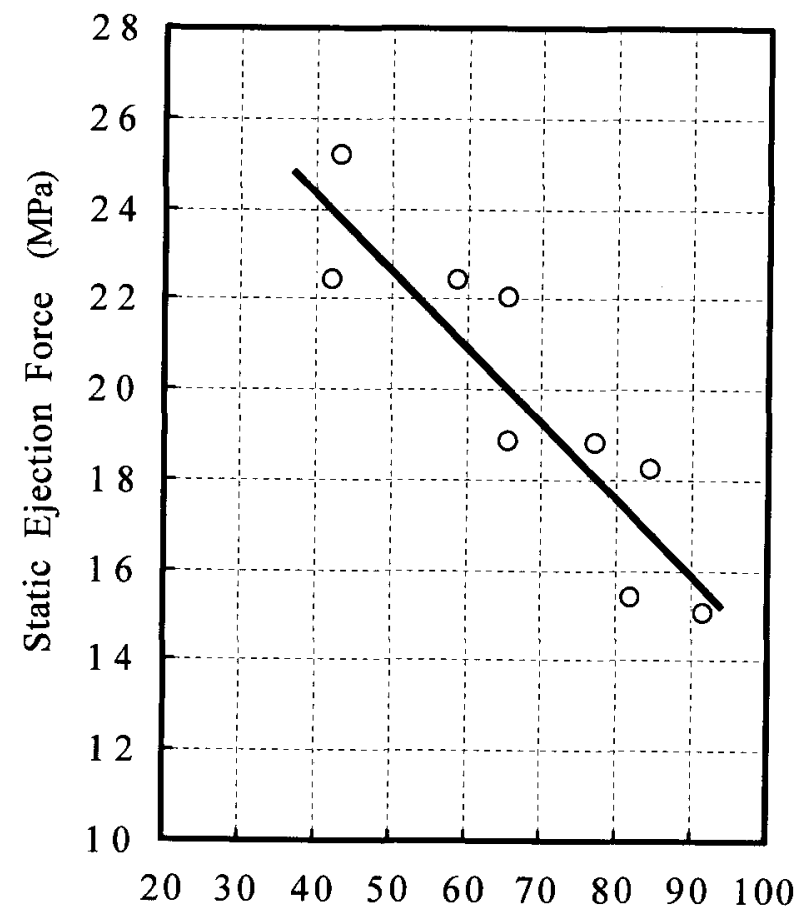

Rate of Projected Area of Lubricant (\%)

(a)

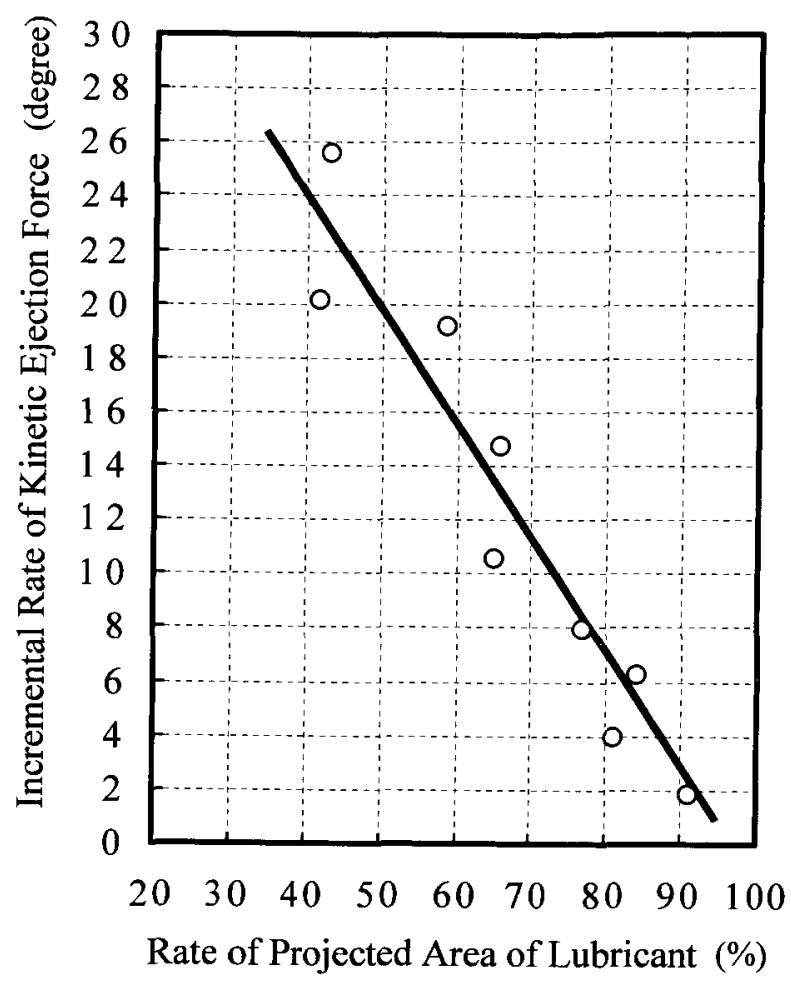

(b)

Fig.11 Relationship between (a) static ejection force, (b) incremental rate of kinetic ejection force and rate of projected area of lubricant in diewall lubrication method (die lubricant: Zinc-stearate, powder lubricant: 0.05 mass\% Zinc-stearate, compacting pressure: $700 \mathrm{MPa}$ ).

原子が同一面上に順序よく並んで形成された金属平面とここ の平面に対し，くし状に規則正しく並んだ脂肪酸鎖とから 成っていると言われるの.そのため層間で結晶がすべり破壊し やすい，さらに亜鉛は六方最密格子の結晶を持ち，異方性が 強く強度が小さい.これらの特性が相まって, 抜出し時に潤 滑剤粒子のせん断䢃開が效率良く進行した結果, 潤滑棛微粒 子が成形体とダイス内壁面との境界に数多く存在するように なり良好な抜出し性を示すものと考えられる.Fig.7で動的抜 出し圧力の增加係数が $400 \mathrm{MPa}$ で最大になったのは, このよ うな低圧力域では拢出し時に発生するせん断力が低く，潤滑 鼡粒子の層間すべりが小さかったためと考えられる.

またステアリン酸リチウム $\left.\left(\left(\mathrm{C}_{17} \mathrm{H}_{35} \mathrm{COO}\right) \mathrm{Li}\right)\right)$ の潤滑性は, ス テアリン酸覀鉛と同様に結晶の層間割れによって生ずると考 えられるが，結晶が小さく層間距離も短いので層間強度が大 きくなり，せん断破罗がステアリン酸亜鉛のように容易では ないのであろう.

エチレンビスアミド $\left(\left(\mathrm{C}_{17} \mathrm{H}_{35} \mathrm{CONH}\right)_{2}\left(\mathrm{CH}_{2}\right)_{2}\right)$ のような合成 ワックスは，主に粒子の延性によって潤滑性を発現する。し かし粉末冶金の抜出し工程のように摺動距離が比較的長く, 摩擦境界面の凹凸が大きな環境下では，十分にその性能を発 揮しないのであろう.

次に, 鉄粉粒度が静的抜出し圧力と動的抜出し压力の増加 係数に及ほす影響について考察する．Fig.12は成形体密度に
及ぼす成形圧力の影響を示す。成形体密度は抜出した成形体の 直径, 高さ,ならびに重量を測定して算出した. 例えば $200 \mathrm{MPa}$ の低圧成形では鉄粉粒度による密度差は $0.16 \mathrm{Mg} / \mathrm{m}^{3}$ と比較的 大きいが, 成形圧力の上昇とともにその差は減少し，1000 MPa ではわずか $0.04 \mathrm{Mg} / \mathrm{m}^{3}$ となる.一方, Fig.5の鉄粉粒径と静的 抜出し圧力の関係では, $600 \mathrm{MPa}$ 以上の圧力で粒径の影響が顕 著になっていた。よって鉄粉粒径の大小による静的抜出し圧 力の差異は成形体密度には直接関係するものではなく，鉄粉 粒子とダイス壁面との実質接触面積の相違によるものと考え られ，また動的抜出し圧力の増加係数 (Fig.7)は，ステアリン 酸亜鉛粒子の擘開破壊が容易に進行し十分に潤滑粒子膜を形 成するため，鉄粉粒径の影響を受けないものと考えられる。

成形圧力をパラメーターにした実験では1000MPa以上で静 的拢出し圧力ならびに動的抜出し圧力の增加係数が低下する 傾向にある.これは，鉄粉粒子とダイス壁面の実質接触面積， 金型の弾性変形及び成形体の剛性等が変化するためと考えら れるわ。

\section{2 金型潤滑法における抜出し性}

前述のように，金型潤滑法では塗布面積率約 $90 \%$ で粉末潤 滑法と同等の抜出し性を示す。粉末潤滑法で鉄粒子と潤滑郕 粒子が単純に混合していると仮定して計算すると,1 mass\%の ステアリン酸两鉛を鉄粉に添加して圧粉した密度 $7.15 \mathrm{Mg} / \mathrm{m}^{3}$ の成形体の潤滑剂体積含有率は6\%程度になる。したがって， 


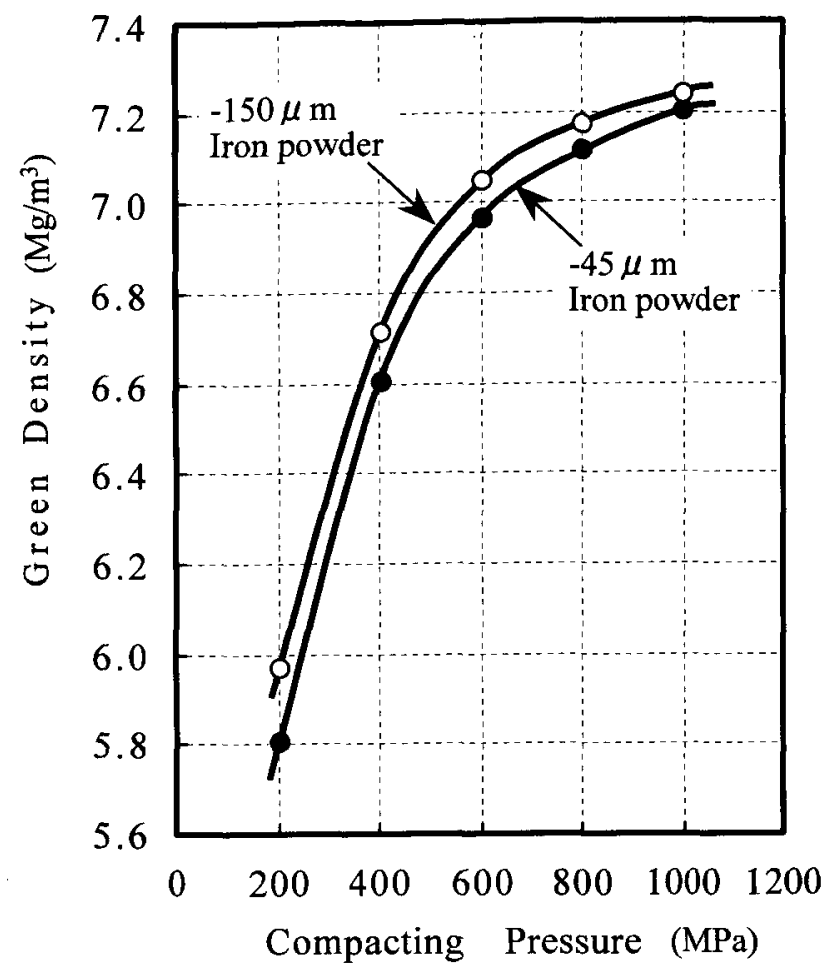

Fig.12 Effects of compacting pressure and powder grain size on green density in povider lubrication method (lubricant: 1 mass\% Zinc-stearate).

金型潤滑における塗布面積率も6\%近傍で粉末激滑法と同等の 抜出し性を示すべきであるのに，実験では約 90\%の高い面積 率が必要であった。これは混合機で十分に混合することによ り，鉄粉粒子の周りを数多くの潤滑剂粒子が取り巻く状態に なっているためと思われる。

高い塗布面積率を得るのに有効な静電粉体金型潤滑手法は 複数回の塗布 (多段塗布法)を行うことが必要であった。

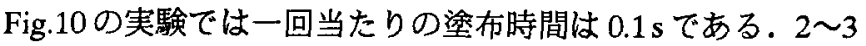
回の塗布を繰り返しても所要時間はわずかであり，工業的に は十分に有効な手法であると言える。開放された空間ではな いダイスキャビティ内では，塗布の際に発生する空気の流れ が面積率の大小を大きく左右する. 多段塗布法では，空気流 による付着潤滑剤粒子の脱落，あるいは空気流同士の衝突に よる粒子の付着阻害等の悪影響を最小限にとどめることがで き，高い面積率を得ることができるものと考えられる.

粉末潤滑法は圧粉成形中の粉末間潤滑にまず効果的であり， 金型潤滑法は成形体と金型間潤滑に効果的である。後者は特 に拔出し性に影響が現れる。一方, 成形体の高密度化には原 料粉末内への潤滑剂添加量の削減加有效的である. 前報の結 果から純鉄系や鉄一黒鉛系の圧粉成形には，粉末間摩擦を考 慮しても極微量の 0.05 mass\% 添加でよいと言う知見を得た。 続いて本実験では成形体と金型(ダイス内壁面)間の潤滑を補 うための金型潤滑を施し，抜出し性を評価した.その結果, 潤 滑剤添加量 0.05 mass\%の試料粉末を用いた成形においても十
分な抜出し性が得られ，静電粉体金型潤滑による高密度化へ の指針を得ることができた.

\section{5 結 論}

金型潤滑を用いた高密度化粉末成形法の開発を進めるにあ たり，潤滑法，潤滑剂，成形圧力，ならびに鉄粉粒度が円柱 成形体の抜出し性に及ぼす影響を検討した。ことに，拔出し 工程を静摩擦段階と動摩擦段階に分けることにより，次の新 たな知見を得た。

(1) 静的抜出し圧力と成形体表面性状の相関は乏しい.動摩擦 力下での動摩擦増分による評価が重要で，成形体表面性状 に大きな影響を与える。

(2) 鉄系粉末の成形では,ステアリン酸リチウムやエチレンビ スアミドなどの潤滑剤に比較して,辟開破㯖性に優れたス テアリン酸要鉛の静的抜出し圧力は高いが,動的拔出し圧 力の增加係数付小さく潤滑性に優れている.

(3) 成形圧力が大きくなるといずれの润滑剤も静的拔出し圧力 が大きくなる.また動的抜出し圧力の增加係数はステアリ ン酸要鉛の場合, 他の潤滑剛に比べきわめて低水準で，し かも成形圧力が増すにつれて減少し,鉄粉粒径が及ぼす影 響は小さい。

(4) 静電粉体金型潤滑法において,潤滑剤粒子の塗布投影面積 率が約90\%以上で良い潤滑性を示す.それには1回当たり の塗布時間を短くした多段塗布法が適している.

\section{文献}

1) W.G.Ball, F.W.Hinger, R.A.Mckotch and H.D.Pfingstler: "REPLACING INTERNAL WITH EXTERNAL LUBRICANTS", ADVANCES in Powder Metallurgy \& Particulate Materials, 3(1994)71-82.

2) W.G.Ball, F.W.Hinger, R.A.Mckotch, H.D.Pfingstler and R.R.Phillips: "REPLACING INTERNAL WITH EXTERNAL LUBRICANTS: PHASE II", ADVANCES in Powder Metallurgy \& Particulate Materials, 1(1995)2-11-2-23.

3) W.G.Ball, P.F.Hibner, F.W.Hinger, J.E.Peterson and R.R.Phillips: "REPLACING INTERNAL WITH EXTERNAL LUBRICANTS: PHASE III TRIBOSTATIC APPLICATION OF LUBRICANTS ONTO DIE WALLS", ADVANCES in Powder Metallurgy \& Particulate Materials, 2(1996)6-3-6-14.

4) 上田勝彦, 町田輝史: "鉄系粉末の金型潤滑成形における添 加潤滑剤の挙動", 粉体および粉末冶金, 47(2000)1051-1055.

5) W.G.Ball, P.F.Hibner, F.W.Hinger, J.E.Peterson and R.R.Phillips: "New Die Wall Lubrication System", The International Journal of Powder Metallurgy, 33(1997)23-24.

6) 吉田時行, 進藤信一ほか: 金属せっけんの性質と応用, 幸 書房, (1995)36.

7) 沖本邦郎, 佐藤富雄, 山川俊夫: "金属圧粉体を金型から押 し抜くときの圧粉体と金属間の摩擦係数についで,九州工 業技術試験所報告, 13(1975)742. 